\title{
Locus of Control as a Moderator of the Effects of Organizational Commitment and Pay-for- Performance on Performance of Tax Officers
}

\author{
Agus Bandang ${ }^{1}$, Asri Usman ${ }^{1}$, Made Gde Satria Bela ${ }^{2}$ \\ ${ }^{1}$ Hasanuddin University, Indonesia \\ ${ }^{2}$ Secretariat General of Minister of Finance of the Republic of Indonesia \\ rahmawati345@yahoo.co.id
}

\begin{abstract}
This study aims to determine the effect of organizational commitment and pay-for-performance on performance of tax officers with locus of control as moderating variable. This research is a quantitative descriptive study. Data on this research was obtained through questionaires. Population of this study consists of 104 tax officer of South Makassar Small Taxpayers Office of which is randomly chosen 83 tax officers as a sample to answer research questionnaires. Analysis of this study is using regression analysis with residual analysis method to test the effect of moderating variable. The results of this research indicate that (1) organizational commitment has a positive effect on performance of tax officers, (2) locus of control is able to moderate the effect of organizational commitment on performance of tax officers, (3) pay-for-performance has a positive effect on performance of tax officers, and (4)) locus of control is able to moderate the effect of pay-for-performance on performance of tax officers.
\end{abstract}

Keywords: Organizational commitment, pay-for-performance, locus of control, performance, tax officers

\section{Introduction}

Taxes play an important role for the government because tax revenues are the main source of state revenues in Indonesia that needed for financing the government spending as well as the key point of implementation the sustainable national development. The contribution of revenues from tax sector managed to provide more than $80 \%$ of total state revenue. Thus without taxes, most of the government spending activities are hardly undertaken. However, during the last decade, the realization of tax revenue target was only achieved in 2008. The performance realization from several types of tax showed the growth was slowed down due to the volatility of the global economic condition affecting the domestic economy, while on the other hand; state tax revenues target is increasing from time to time. Therefore, the Directorate General of Taxes (DGT) needs to implement strategic policies and technical policies that can improve the achievement of tax revenue and also continue tax reform to continuously improve the DGT's performance. There are two important elements of tax reform, first, DGT institution itself and, second, its human resources. Improving the management control system is needed to be done to help implementation of tax reform, so there will be a goal congruences between the employees and the organization. Employees' performance is the key elements in increasing the organization performance. According to Gibson et al. (2012:10), individual performance is the foundation of organizational performance. This employees performance establishes the organization performance, thus understanding individual behavior is therefore a critical issue for creating effective management control system.

The strategic objectives of DGT's human resources management development is the formation of excellent performance employee. DGT's institutional strengthening in human resources management sector is directed to achieve the objective of excellent performance employee, marked by high level of competence, satisfaction, and employees commitment. The character, attitude, behavior and work culture of a competence DGT's employee, depend on his or her commitment in realizing the excellent performance. The commitment strength of every employee will support the achievement of DGT's objectives. However, the phenomenon that often occurs in an organization is not achieved organizational goals caused by high turnover rate and high absenteeism of the employee, which is an indication of the low level of organizational commitment owned by employees. Employees with low levels of organizational commitment have great potential to negatively affect performance of both colleagues and organization as a whole. Organizational commitment is one of the internal factors that can affect employee performance. Organizational commitment, according to Mowday, Steers and Porter (1979: 226), represents a strong belief in and acceptance of the organization's goals and values, a willingness to exert considerable effort on behalf of the organization, and a strong desire to maintain membership in the organization. Some studies suggest that there is a positive relationship between 
organizational commitment and employee performance. According to Meyer et al. (2002: 36) affective and normative commitment correlated positively, and continuance commitment correlated negatively, with job performance. Study conducted by Marganingsih \& Martani (2010) showed that organizational commitment proved to have a positive effect on performance. The result of Nydia's (2012) study stated that organizational commitment consisted of affective commitment and continuance commitment have a positive effect on performance, whereas normative commitment has positive effect but not significant on employee performance. However, Murty \& Hudiwinarsih (2012) found that organizational commitment partially had no significant effect on performance. Organizational commitment, therefore, remains one of the challenging and intriguing concepts of study in the field of behavior.

The next targets from human resources management development in order to encourage the optimization of DGT's organizational performance are the provision of competitive compensation for employees. The implementations was the issuance of Presidential Regulation No. 37 Year 2015 regarding Performance-Based Benefit of the Directorate General of Taxes' Employee. Provision of performance-based benefits (pay-forperformance) is one of the tool for management to control its employee's behavior. It is hoped that with the existence of competitive performance-based benefits can create goal congruence between tax officer and DGT institution, so with the motivation of employee in doing their job will increase the achievement of tax revenue target as the purpose of organization. Pay-for-performance is one of the external factors that influence the effort in improving employee performance. Several previous studies have shown that giving a performancebased benefits has a positive effect on employee performance. Studies conducted by Muryanto (2011) \& Iqbal et al. (2013) show that compensation including benefits has a significant effect on employee performance. The results of this study also supported by Hardani et al. (2016) which states that the pay-for-performance affects the performance of civil servants. However, research conducted by Marganingsih \& Martani (2010) states that monetary rewards, in the form of salaries and benefits, are not proven to have a positive effect on performance. Murty \& Hudiwinarsih (2012) also shows that compensation has no significant effect on employee performance.

Both pay-for-performance and organizational commitment are a condition and behavior that affect employee performance. The condition that comes from within the individual is called the internal factor (individual), while the condition that comes from outside the individual is called the external factor (situational). The factors that affect the performance consist of internal factors and external factors (Mangkunegara, 2006:15). These internal and external factors are the types of attributions that affect one's performance. The application of attribution theory in behavioral accounting study is using locus of control variable. Using locus of control, work behavior may be explained by whether employees perceive their outcomes as controlled internally or externally (Luthans, 2011:174). According to Rotter (1966:1) locus of control is define as the degree to which the individual perceives reinforcement or outcome in their lives. A person termed as an individual who has internal locus of control, if the person perceives that the event is contingent upon his own behavior or his own relatively permanent characteristics, so when they perform well, they belief that it is due to his own efforts. While individuals with external locus of control expect that the reinforcement or outcome is a function of chance, luck, or fate, are under the control of powerful others, or is simply unpredictable, so when they perform well they are convinced that it is luck.

Study conducted by Abdulloh (2006) shows that locus of control has a positive effect on employee performance. The results of this study are also supported by Erdawati (2015) which shows that locus of control has a positive effect on employee performance. It can be said that the stronger the locus of control the stronger the performance of employees (Ayudiati, 2010: 58). More detailed results indicated by Saputra (2012) study which states that internal auditors who have internal locus of control show higher performance than internal auditors who have external locus of control. In this study, we analyzed the organizational commitment and pay-for-performance on performance of tax officers. The difference of this study with previous studies lies in using locus of control as moderating variables. The use of other variables acting as a moderating variable is a contingency approach used in resolving differences due to inconsistencies in results from various studies. By means of whether organizational commitment and pay-for-performance will increase or decrease performance depending on contingency variables that moderate the relationship between these variables. Coleman, Irving, and Cooper (1999:999) found significant relations between locus of control and organizational commitment, specifically, significant relations between internal locus of control 
and affective commitment. In addition, the relationship between locus of control and reward, according to Spector (1982:493) that organizational setting in which rewards are tied to performance would be expected to work well with internals and poorly with externals. Thus, we assume that internal locus of control will increase the relationships between organizational commitment and employee performance, and will also improve the relationship between pay-for-performance and employee performance.

We conducted study on tax officer at one of vertical unit of Directorate General of Taxes of Ministry of Finance of the Republic of Indonesia, that is South Makassar Small Taxpayers Office (SMO) which have working area i.e. sub-district Panakkukang, Manggala, Rappocini, and Makassar. As one of the tax office that serves taxpayers in the business district of Makassar City, South Makassar SMO employees are required to perform excellently in providing services to taxpayers and to increase tax revenue. Excellent performance employee is characterized by a high commitment to the organization. Also, employees of South Makassar SMO have received a pay-for-performance in accordance with Presidential Regulation No. 37 Year 2015 in order to improve employee performance. The purpose of this study are to test and analyze the effect of organizational commitment and pay-for-performance on the performance of tax officers, and also the effect of organizational commitment and pay-for-performance on the performance of tax officers moderated by the locus of control.

\section{Literature Review}

Attribution Theory: Attribution theory helps us to understand how people perceive the causes of events, assess responsibility for outcomes, and evaluate the personal qualities of the people involved (Schermerhorn et a., 2014:61). The attribution process involves deciding whether an observed behavior or event is caused mainly by the person (internal factors) or by the environment (external factors) (McShane et al., 2010:75). When we observe an individual's behavior, we attempt to determine whether it was internally or externally caused (Robbins and Judge, 2013:168). That determination, however, depends largely on three factors:

- Distinctiveness, refers to whether an individual displays different behaviors in different situations.

- Consensus, if everyone who faces a similar situation responds in the same way.

- Consistency, if the person responds the same way over time.

Expectancy Theory: Victor Vroom's expectancy theory says a person's motivation to exert some level of effort depends on three things: the persons expectancy (in terms of probability) that his or her effort will lead to performance; instrumentality, or the perceived connection (if any) between successful performance and actually obtaining the rewards; and valence, which represents the perceived value the person attaches to the reward (Dessler, 2012:394). Expectancy theory argues that the strength of our tendency to act a certain way depends on the strength of our expectation of a given outcome and its attractiveness. In more practical terms, employees will be motivated to exert a high level of effort when they believe it will lead to a good performance appraisal; that a good appraisal will lead to organizational rewards such as bonuses, salary increases, or promotions; and that the rewards will satisfy the employees' personal goals (Robbins and Judge, 2013:224).

Reinforcement Theory: Reinforcement theory sees behavior as a consequences of environment. B.F. Skinner's reinforcement/behavior modification theory means changing behavior through rewards or punishments that are contingent on performance. There are two main principles, first, that behavior that appears to lead to a positive consequence (reward) tends to be repeated, whereas behavior that appears to lead to a negative consequence (punishment) tends not to be repeated; and second, that, therefore, managers can get someone to change his or her behavior by providing the properly scheduled rewards (or punishment) (Dessler, 2012:395). Usingarewardto encourage high performance is consistent with dengan reinforcement theory, which holds that behavior is caused by chains of antecedents and consequents. A key principle from reinforcement theory is thus that compensation should be based on performance so that better performers receive more than low performers, in practice is known as pay-for-performance (Stewart and Brown, 2011:419-420).

Performance: Performance means a result of work or work achievement. Job performance is a contribution that individuals make to the organization that employs them (Stewart and Brown, 2011:297). Mangkunegara (2006:9) defines performance of employees as work achievement or output both quality and quantity 
achieved by employees in period of time in carrying out their work duties in accordance with the responsibilities given to him. Performance appraisals are used to assess an employee's performance and provide a platform for feedback about past, current, and future performance expectations (Mathis \& Jackson, 2011:329). The objectives of performance appraisals are to reward past performance and to motivate future performance improvement (Gomes, 2003:135). The tax officers' performance of this study was assessed by dimensions according to Chung and Megginson (1981: 375-376) in Gomes (2003: 142), as follows.

a. Quantity of work, the amount of work specified in a period of time.

b. Quality of work, the suitability of work quality based on the conditions specified.

c. Job knowledge, the breadth of knowledge about jobs and skills possessed.

d. Creativeness, authenticity of ideas raised and actions to solve problems.

e. Cooperation, willingness to cooperate with others.

f. Dependability, awareness and can be trusted in terms of attendance.

g. Initiative, the spirit to carry out new tasks and have initiatives in their work.

h. Personal qualities, integrity, leadership, hospitality, and professionalism.

Organizational commitment: Organizational commitment is the degree of loyalty an individual feels toward the organization (Schermerhorn et al., 2014:85). Commitment is a psychological state that characterizes the employee's relationship with the organization, and has implications for the decision to continue or discontinue membership in the organization (Meyer and Allen, 1991:67). Meyer and Allen identified three distinct themes in the definition of organizational commitment in the three-component model include three approaches as affective, continuance and normative commitment as described below.

a. The affective component of organizational commitment, proposed by the model, refers to employees' emotional attachment to, identification with, and involvement in, the organization. Employees with strong affective commitment remain with the organization because they want to (Meyer and Allen, 1990:1-3).

b. The continuance component refers to commitment based on the costs that employees associate with leaving the organization. This means there is an advantage associated with the continuity of participation in the organization and also the costs associated of leaving the organization. Employees with strong continuance commitment remain with the organization because they need to (Meyer and Allen, 1990: 1-3).

c. The normative component refers to employees' feelings of obligation to remain with the organization. The internalization of normative believes in the duty and obligation to make a person feel obliged to continue his membership in the organization. Employees with strong normative commitment remain with the organization because they feel they ought to do so (Meyer and Allen, 1990: 1-3).

Pay-for-performance: Pay-for-performance is one of the component of compensation in financial form of direct payment pay which is a quantitative reward received by employees in return for their performance. The overall purpose according to Mondy dan Martocchio (2016:247) is to attract, retain, and motivate employees. Pay-for-performance are incentive plans that tie employee's pay to the employee's performance (Dessler, 2012:395).Pay-for-performance represents income other than salary given to employees based on competence and performance. Pay-for-performance within the Ministry of Finance are given to the employees monthly in accordance with employee's grading and employee's performance achievement, especially within the DGT is also based on the performance of the tax revenue realization. Performance of each employee is measured in accordance with the achievement of performance indicators targets that have been set. Through this mechanism, then the output of employees can be assessed objectively and then the assessment results are used as a reference in determining the performance-based benefits received.According to Sidig (2016: 45) performance allowances are relativelly measured to the following dimensions.

a. Employee's performance, realization of performance indicators, quality of work, and achievements of tax revenue realization.

b. Employee's potentials, technical competence, work experience, and level of education.

c. Employee's activities, workload, working hours and job risk level.

d. Employee's contribution to organizational productivity, tenure and work experience.

e. Employee's needs, ability to meet the primary needs. 
Locus of Control: Locus of control is defined as a person's general belief about the amount of control he or she has over personal life events (McShane et al., 2010:45).Locus of control refers to the degree to which persons expect that a reinforcement or an outcome of their behavior is contingent on their own behavior or personal characteristics versus the degree to which persons expect that the reinforcement or outcome is a function of chance, luck, or fate, is under the control of powerful others, or is simply unpredictable because of the great complexity of the forces surrounding them (Rotter, 1966:1). A person who perceive internal locus of control fell that they personally can influence their outcome through their own ability, skills, or effort. A person who perceives external locus of control fell that their outcomes are beyond their own control, that external forces such as luck control their outcomes.Locus of control consists of the following dimensions.

a. Internals, a person's feelings as if the consequences of his actions depend on his personal behavior or characteristics, and believe that destiny is controlled by oneself.

b. Externals, a person's belief that what happens to him is beyond his control and determined by external forces, and assumes that outcomes are the result of luck, destiny or opportunity, and the consequences are usually unpredictable.

The Effects of Organizational Commitment on Performance: Meyer dan Allen in three-component model of commitment theory express organizational commitment perceived by employees as a simultaneous mindset that includes affective, normative and continuance commitment. This commitment is a construct of work attitude that reflects a fundamental evaluation of one's work experience and which will ultimately predict behaviors such as turnover and employee performance. The study results of Mguqulwa (2008), Marganingsih \& Martani (2010), Nydia (2012), Memari et al. (2013), and Giri et al. (2016) showed that organizational commitment has a positive effect on performance. This results are in accordance with Mowday, Steers and Porter (1979) suggesting that organizational commitment may lead to higher levels of performance. Based on the description earlier, we assume that someone who has a commitment to the organization will have a positive impact on performance. The following hypothesis summarizes the prediction that performance depends on organizational commitment.

H1: Organizational Commitment has a positive effect on performance of tax officers

The Effects of Organizational Commitment and Locus of Control on Performance: Employees' initial commitment to an organization is determined largely by their individual characteristics and how well their early job experiences match their expectations (Hellriegel et al., 2011:92). Personality characteristics can be explained by attribution theory, according to Gibson et al. (2012:97) is a causes of one's behavior. Attribution theory provides insight into the process by which we assign cause or motives to people's behavior that emphasize some aspect of the individual (dispositional attribution) or emphasizes the environment's effect on behavior (situational attribution). One's personality characteristics can be described from their locus of control, which explains how people see the control of their lives as coming from inside themselves (internalizers) or people who believe that their lives are controlled by external factors (externalizers) (Qamar et al., 2012:111). Several studies showed locus of control associated with affective commitment (McMahon, 2007: 35) that in accordance with what described by Meyer et al. (2002: 32) in meta-analysis of variables associated with organizational commitment i.e. external locus of control negatively associated with affective commitment. Locus of control also was related to normative commitment and continuance commitment, such that individuals with internal locus of control tend to feel obligated to their organizations and those with external locus of control tend to report a need to work for their organizations (McMahon, 2007:35).Locus of control also have a significant relations with organizational commitment, specifically, significant relations between internal locus of control and affective commitment (Coleman, Irving, \& Cooper, 1999:999). Other studies have also find that locus of control and organizational commitment have a positive effect on performance (Julianingtyas, 2012).Internal locus of control affecting organizational commitment, so the effect of organizational commitment to performance will also increase. The following hypothesis summarizes the prediction described above.

H2: Locus of control moderates the effect of organizational commitment on performance of tax officers

The Effects of Pay-for-performance on Performance: Attribution theory explains that one's behavior can be caused by a combination of internal factors and external factors. Based on these two factors, one will be 
motivated to understand the environment and the causes of certain events. The expectancy theory states that individuals are motivated to work when they believe that effort will be followed by a particular level of performance (expectancy), performance will lead to reward (instrumentality), and satisfaction that an individual feel toward the rewards (valence). The implication of expectancy theory to motivate employees is changing one's expectations of the effort-to-performance, performance-to-reward, and reward valence relationships (Hellriegel et al., 2011; McShane et al., 2010). To improve employees' performance, the organization must ensure that the employees believe that successful performance will in fact lead to getting reward. Using compensation mechanisms, incentive can be a powerful if linked to employees performance. The compensation system that link rewards to performance is known as pay-for-performance. The concept of pay-for-performance is also consistent with the reinforcement theory. It states that behavior that appears to lead to a positive consequence (reward) tends to be repeated, and someone can change his or her behavior by providing the properly scheduled rewards (Steward, 2011; Dessler, 2012). The principle is that compensation should be based on performance so that better-performing employees earn higher payouts. Bonner et al. (2000) indicates that financial incentives have a positive effect on performance. Muryanto (2011) also found a positive and significant influence of compensation on performance. It is also supported by Hardani et al. (2016) state that performance-based benefits have a significant positive effect on the performance of civil servants. In accordance with the expectancy theory and reinforcement theory, we assume that incentive given to employees on the basis of its performance has a positive effect that can increase their employees' performance. The following hypothesis summarizes the prediction described above.

H3: Pay-for-performance has a positive effect on performance of tax officers

The Effects of Pay-for-performance and Locus of Control on Performance: Pay-for-performance is one of the environmental factors that affect one's performance, which is also related to their behavior. In the expectancy theory Vroom (1964) explained that effort will lead to good job performance and that good performance will lead to rewards. If an individual hold both expectancies strongly, he or she will have high job motivation and will perform well (Spector, 1982:487). If related to locus of control, then someone who has internal locus of control should hold higher expectancies of both varieties than externals would, thus, internals are motivated to perform better. Internals will show greater effort towards achieving rewards or achieving goals because they are more likely to believe their efforts will result in good performance. Spector (1982) states that organizations that link rewards to performance or performance-based reward systems will motivate someone with internal locus of control to perform better than external. According to Spector (1982: 488), employee with internal locus of control will perform better than externals in complex task situations because they exhibit stronger beliefs in their own competence as well as the likelihood of rewards being accepted. Hyatt (1995), Hyatt and Prawitt (2001), Noer \& Raharjo (2007) studied the relations between locus of control and performance, stated that performance was affected by locus of control. Julianingtyas (2012) and Erdawati (2015) also supported this result, which suggest locus of control has a positive effect on performance. Based on the description above, we assume that locus of control affects a person in achieving performance with performance-based rewards as a motivation, thus, improving the relationship between pay-for-performance and employees' performance. The following hypothesis summarizes the prediction described above.

\section{H4: Locus of control moderates the effect of pay-for-performance on performance of tax officers}

\section{Methodology}

Participants and Data Collection Procedure: The population of this study is all employees at South Makassar SMO consisting of 104 employees. Sampling technique used to determine total sample of this study is probability sampling with simple random sampling technique. Determination of the number of samples in this study using Slovin formula in Sujarweni and Endrayanto (2012: 17). Thus, the study sample taken for a population of 104 tax employees at $95 \%$ confidence level, and 5\% error rate are 83 respondents. Data collection techniques conducted in this study is using questionnaires that were delivered to employees at South Makassar SMO. 


\section{Instruments}

Performance: Performance instruments use the scale adopted from Nydia (2012) based on Chung and Megginson (1981) as well as Gomes (2003: 142) indicators. This instrument consists of 14 items of statements that have choices from strongly agree (5) to strongly disagree (1). Cronbach Alpha value of organizational commitment is 0.924 . Cronbach Alpha value of Performance is 0.882 .

Organizational Commitment: Organizational commitment instruments adopt the Organizational Commitment Scale (OCS) developed by Meyer, Allen and Smith (1993). This instrument uses 15 statement items, i.e. 5 Affective Commitment Scale items (ACS), 5 Continuance Commitment Scale items (CCS), 5 Normative Commitment Scale items (NCS), which have choices from strongly agree (5) to strongly disagree (1).

Pay-for-performance: Pay-for-performance instrument adopted from Sidig (2016) and based on Presidential Regulation No. 37 Year 2015. This instrument consists of 12 items of statements that have choices from strongly agree (5) to strongly disagree (1). Cronbach Alpha value of pay-for-performance is 0.953.

Locus of Control: The locus of control instrument adopted the Work Locus of Control Scale (WLCS) developed by Spector (1988). WLCS is a measurement of locus of control in the work environment. This instrument uses 8 items of WLCS Spector (1988) which has a score of 1 (strongly disagree) to 6 (strongly agree).Cronbach Alpha value of locus of control is 0.949 .

The result from validity test of instrument of organizational commitment, pay-for-performance, locus of control, and performance by using Pearson's Correlation Product Moment showing all item of the statement are valid because it has significance value $<0,05$.

Analysis: Data analyzed using IBM SPSS Statistics 23 and hypotheses tested by using regression analysis. The method used to test the effect of moderating variable is residual test. This method is used because interaction test and absolute difference test has a tendency to occur high multicollinearity among independent variables, so that would violate the classical assumption in ordinary least square regression (OLS). This residual analysis tests the effect of deviations from a model that focuses on the mismatch resulted from the deviation of the linear relationship between the independent variables. If there is a match between independent variables and moderator variables (small or zero residual values) i.e. high independent variables and moderation variables are also high, then the dependent variable is also high. Conversely, if there is a mismatch between independent variables and moderation variables (large residual values) i.e. high independent variables and low moderation variables, then the dependent variable will be low. The existence of the moderation variable is shown by the significant and negative regression coefficient $(\beta)$ in the absolute value of residual regression equation, which mean the moderator variable is able to moderate the relationship between the independent variable and the dependent variable (Ghozali, 2016:228).

The equation for the first hypothesis (H1) testing between Organizational Commitment (OC) and Performance $(\mathrm{P})$ is as follows.

$$
\mathrm{P}=\alpha+\beta_{1} \mathrm{OC}+\varepsilon
$$

The steps of residual analysis in the second hypothesis $(\mathrm{H} 2)$ testing with independent variables Organizational Commitment (OC), moderating variable Locus of Control (LOC), and dependent variable Performance (P) are as follows.

$\mathrm{LOC}=\alpha+\beta_{2} \mathrm{OC}+\mathrm{e}$

$|\mathrm{e}|=\alpha+\beta_{2} \mathrm{P}+\varepsilon$.

The equation for the third hypothesis (H3) testing between Pay-for-Performance (PfP) and Performance $(\mathrm{P})$ is as follows.

$$
P=\alpha+\beta_{1} \mathrm{PfP}+\varepsilon
$$

The steps of residual analysis in the fourth hypothesis (H4) testing with independent variables Payfor-Performance (PfP), moderating variable Locus of Control (LOC), and dependent variable Performance (P) are as follows.

$$
\begin{aligned}
& \mathrm{LOC}=\alpha+\beta_{4} \mathrm{PfP}+\mathrm{e} . \\
& |\mathrm{e}|=\alpha+\beta_{4} \mathrm{P}+\varepsilon \ldots \ldots
\end{aligned}
$$


Notes:

\begin{tabular}{|c|c|c|c|}
\hline$\alpha$ & $=$ constant & $|\mathrm{e}|$ & $=$ absolute value of residual \\
\hline & $=$ regression coefficients & $\varepsilon$ & $=$ error \\
\hline
\end{tabular}

\section{Result}

\section{Assumptions of The Classical Model Test}

Normality Test: Normality test is done by using histogram and normal probability plot analysis. Based on the histogram graphical view and the normal probability plot it can be concluded that the histogram graph shows the normal distribution pattern, whereas in the normal graph the probability plot shows spots spread around the diagonal line and follows the direction of the diagonal line. These two graphs show that the regression model meets the assumption of normality. The results of the graph analysis show that the residual data is normally distributed. It is also reinforced by Kolmogorov-Smirnov (K-S) statistical test with the value of Test Statistic K-S is 0.076 and the probability value of Monte Carlo significance is 0.701> 0.05, so it can be concluded the residual data is normally distributed.

Heteroscedasticity Test: Heteroscedasticity test was performed by using glejser test. Based on the results of glejser test, there is no independent variables statistically significant affect the Absolute Residual of Performance (AbsUt). The probability value of significance above the confidence level $5 \%$. So, it can be concluded the regression model does not contain any heteroskedasticities in the error variance. The glejser test giving the following results.

\begin{tabular}{|c|c|c|c|c|c|c|c|c|}
\hline$|\widehat{\mathrm{Ut}}|$ & $=$ & 7,725 & $-0,055$ OC & $+0,008 \mathrm{PfP}$ & $-0,057$ LOC & & & \\
\hline se & $\begin{array}{l}= \\
=\end{array}$ & $\begin{array}{l}(2,516) \\
(3,071)\end{array}$ & & & & $\mathrm{R}^{2}$ & $=$ & 0,011 \\
\hline
\end{tabular}

\section{Hypothesis Testing}

First Hypothesis Testing: The first hypothesis testing (H1) between organizational commitment (OC) and performance $(\mathrm{P})$ is using linear regression analysis. The regression is presented in the following results.

\begin{tabular}{|c|c|c|c|c|c|c|}
\hline$\widehat{P}$ & $=$ & 48,795 & $+0,180 \mathrm{OC}$ & & & \\
\hline se & $=$ & $(3,134)$ & $(0,056)$ & & & \\
\hline $\mathrm{T}$ & $=$ & $(15,572)$ & $(3,196)$ & $\mathrm{R}^{2}$ & $=$ & 0,101 \\
\hline
\end{tabular}

The regression result shows that the adjusted $\mathrm{R}^{2}$ is 0.101 . This means that $10.1 \%$ of performance variation can be explained by organizational commitment, while the remaining $89.9 \%$ is explained by other variables or causes by other beyond the model. The regression coefficient value of organizational commitment is 0.180 and the $t$ value is 3.196 with a probability significance of 0.002 far below 0.05 . This means that the performance is affected by organizational commitment.

Second Hypothesis Testing: The second hypothesis test (H2) between organizational commitment (OC) and performance of tax officers (P) with locus of control (LOC) as moderator variable, is using residual test. The regression of the absolute value of the locus of control $\left(\mathrm{X}_{3}\right)$ residuals obtained from regression with organizational commitment $\left(\mathrm{X}_{1}\right)$, were regressed on performance $(\mathrm{Y})$, giving the following results.

\begin{tabular}{|c|c|c|c|c|c|c|}
\hline$\widehat{|\mathrm{e}|}$ & $=$ & 17,273 & - 0,186 Performance & & & \\
\hline se & $=$ & $(5,409)$ & $(0,092)$ & & & \\
\hline $\mathrm{T}$ & $=$ & $(3,193)$ & $(-2,030)$ & $\mathrm{R}^{2}$ & $=$ & 0,037 \\
\hline
\end{tabular}

The results of residuals test above shows the regression coefficient parameters value is -0.186 with probability significance of 0.046 . A variable is said to be a moderator variable if it has a negative and significant parameter coefficient value. Thus the locus of control is considered as a moderator variable 
because it has a negative and significant parameter coefficient value at $5 \%$ error rate which means it can strengthen the relationship between organizational commitment and performance.

Third Hypothesis Testing: The third hypothesis test (H3) between pay-for-performance (PfP) and performance $(\mathrm{P})$ is using linear regression analysis. The regression is presented in the following results.

\begin{tabular}{|c|c|c|c|c|c|c|}
\hline$\widehat{\mathrm{P}}$ & $=$ & 48,902 & $+0,212 \mathrm{PfP}$ & & & \\
\hline se & $=$ & $(3,064)$ & $(0,066)$ & & & \\
\hline $\mathrm{T}$ & $=$ & $(15,958)$ & $(3,235)$ & $\mathrm{R}^{2}$ & $=$ & 0,104 \\
\hline
\end{tabular}

The regression result shows that the adjusted $\mathrm{R}^{2}$ is 0.104 . This means that $10.4 \%$ of performance variation can be explained by pay-for-performance, while the remaining $89.6 \%$ is explained by other variables or causes by other beyond the model. The regression coefficient value of organizational commitment is 0.212 and the $t$ value is 3.235 with a probability significance of 0.002 far below 0.05 . This means that the performance is affected by pay-for-performance.

Fourth Hypothesis Testing: The fourth hypothesis test (H4) between pay-for-performance (PfP) and performance of tax officers (P) with locus of control (LOC) as moderator variable, is using residual test. The regression of the absolute value of the locus of control $\left(\mathrm{X}_{3}\right)$ residuals obtained from regression with pay-forperformance $\left(\mathrm{X}_{2}\right)$, were regressed on performance $(\mathrm{Y})$, giving the following results.

$\widehat{\mathrm{e}} \mathrm{|}=18,608-0,210$ Performance

$\mathrm{se}=(5,402) \quad(0,092)$

$\mathrm{T}=(3,444)(-2,293) \quad \mathrm{R}^{2}=0,049$

The results of residuals test above shows the regression coefficient parameters value is -0.210 with probability significance of 0.024 . A variable is said to be a moderator variable if it has a negative and significant parameter coefficient value. Thus the locus of control is considered as a moderator variable because it has a negative and significant parameter coefficient value at $5 \%$ error rate which means it can strengthen the relationship between pay-for-performance and performance.

\section{Discussion}

Organizational Commitment Positively Affects Performance of Tax Officers: As predicted, organizational commitment has a positive effect on performance of tax officers at South Makassar SMO. Thus, hypothesis 1 is supported because it is empirically proven. These results prove that the organizational commitment can increase performance of the employees. The result of this study is consistent with Giri et al. (2016), Memari et al. (2013), Marganingsih \& Martani (2010), and Mgulqulwa (2008). The results of their research generally state that organizational commitment possessed a positive effect on one's performance. The results of this study reinforce theoretical concepts by Mowday et al. (1979:240-241) that say the commitment to be modestly related to employee performance, that employee who has high level of organizational commitment may also lead to higher levels of performance. This study also confirms the attribution theory. Organizational commitment as an internal factor that comes from within a person affects his behavior. Organizational commitment establishes causal relationships with behavior, which can influence a person in responding behavior and act in the future. Employees tend to show high performance when they associate their success with internal factors. Meyer and Allen (1991:78) said that employees who perform at a high level of proficiency may become committed to that level of performance and, consequently, develop a more positive attitude toward the organization. Once developed, the attitude may ensure the continuation of high level of performance in the future.

Locus of Control Moderates the Effects of Organizational Commitment on Performance of Tax Officers: The results prove that locus of control is a moderating variable in the relationship between organizational commitment and performance of tax officials at South Makassar SMO. Thus, hypothesis 2 is supported because it is empirically proven. The results of this study indicate that the internal locus of control can strengthen the influence of organizational commitment on the performance of the employees, so the higher 
the internal locus of control and organizational commitment that an employee has, the higher the performance of the employee. This result is consistent with Coleman et al. (1999) and Spector (1988) which states that the internal locus of control is related to organizational commitment. Luthans et al. (1987) provided potential explanations for the relationship between locus of control and commitment, i.e. those with internal locus of control are likely to report higher levels of commitment because they perceive that they have control over their work environment, so internals will feel more committed to the organization that they decide to join, and are expected to remain with an organization. This study also confirms the attribution theory. Attribution theory divides the cause of a person's behavior in general that is influenced by self (internal factor) or environment (external factor). Locus of control as a personal characteristic can affect a person's behavior and consequences in their life. Locus of control has two main forms: internal and external. Internals tend to attribute positive outcomes to their abilities and negative outcomes with their weaknesses, while external tend to attribute outcomes to environmental reasons. Internal locus of control would perform better on the job than external because they hold greater expectancies that effort will lead to performance (Spector, 1982: 488). That's also confirms the expectancy theory, which internally exert greater efforts because they show a strong belief in their competence, and ultimately, greater effort should lead to better performance across individuals.

Pay-for-Performance Positively Affects Performance Of Tax Officers: As predicted, pay-for-performance has a positive effect on performance of tax officers at South Makassar SMO. Thus, hypothesis 3 is supported because it is empirically proven. These results prove that using performance-based benefits is the key to increasing the employees' performance because it can encourage employees to work better, so that will impact on improving overall performance of organization. The results of this study is consistent with Hardani et al. (2016), Muryanto (2011), Weibel et al. (2009), and Bonner et al. (2000), which indicates that pay-forperformance or compensation and incentives provided on the basis of performance achievement have a positive effect on employees' performance. Similarly, the results of this study indicate that the implementation of the provision of benefits based on performance can encourage employees to increasing its performance in order to increase state revenue from the taxes sector. This is in line with the objective of the stipulation of Presidential Regulation Number 37 Year 2015 in DGT.

This study also confirms the theory of attribution, i.e. the behavior of a person is determined by the cause or motive in relation to personality characteristics or with the situation where it happens. In this case, someone will respond to the reward to act in the future. When a person is rewarded for a task or a job, they tend to relate his behavior to the reward. In addition, the results of this study also confirm the theory of expectancy and reinforcement theory. According to expectancy theory, performance-reward relationship, where rewards are linked to one's performance, there will be a tendency to meet his performance standards and hoping in maximizing the rewards that they received. According to reinforcement theory, behavior that appears to lead to a reward tends to be repeated, and someone can change his or her behavior with the reward received. Rewards were reliably found to increase the likelihood that the behavior would emit again, an effect that persisted as long as the reward contingency was operative, so rewards can be used as motivational strategies and behavior-change programs (Deci et al., 1999: 627). Similarly, if pay-for-performance associated with performance. Employees tend to link their behavior with pay-for-performance, so they will meet their performance indicators or standard with the hope of getting maximum rewards. This behavior will continue to be repeated, so it can change employees' behavior with pay-for-performance and then it will lead to higher performance of employees.

Locus of Control Moderates the Effect of Pay-for-Performance on Performance Of Tax Officers: The results prove that locus of control is a moderating variable in the relationship between pay-for-performance and performance of tax officers at South Makassar SMO. Thus, hypothesis 4 is supported because it is empirically proven. The results of this study indicate that the internal locus of control can strengthen the effect of pay-for-performance on performance of tax officers at South Makassar SMO, so the higher the internal locus of control and level of satisfaction that an employee feel about pay-for-performance received, the employees' performance will also be higher. This result is consistent with Pisca (2011) which states that an employee with incentive and internal locus of control has higher performance than an employee with an external locus of control. Gagne and Deci (2005) suggests that individuals with internal locus of control are less likely to see external factors such as rewards as a control over their behavior and are, therefore, less 
likely to feel externally controlled over the rewards. Consequently, the individual with the internal locus of control views the reward as an opportunity and indicator of his or her competence, thus experiencing a positive influence on rewards on his intrinsic motivation when he feels responsible for his or her performance.

This study also confirms the attribution theory. Attribution theory divides the cause of a person's behavior in general that is influenced by internal factor or external factor. Locus of control can affect a person's behavior and consequences in their life. Locus of control has two main forms: internal and external. Konopaske et al. (2016:70) explains that in organizational settings, internals usually do not require as much supervision as do externals because they are more likely to believe their own work behavior will influence outcomes such as performance, promotions, and pay. Internal locus of control hold greater expectancies that effort will lead to good performance, and good performance will get reward(Spector, 1982:488). Hal ini sesuai denganTheory expectancy, yang berfokus pada effort-performance relationship dan performance-reward relationship. Clearly, as has been state in reinforcement theory, the locus of control is the common hope of a person with respect to the forces that determine reward and punishment (Rotter, 1966). Desirable or reinforcing consequences (e.g., recognition in the feedback program of doing an excellent job) will increase the strength of a behavior (e.g., high-quality performance) and increase its probability of being repeated. Undesirable or punishment consequences will decrease the strength of a response and decrease its probability of being repeated (Konopaske et al., 2016:164).

\section{Conclusion}

Based on research objectives, hypotheses, and the results of analysis and discussion, then the conclusions of this study are as follows.

- There is a positive effect of organizational commitment on the performance of tax officers at South Makassar SMO. The results of this study indicate that the higher the commitment of employees to the organization, the higher the performance of the employees.

- Locus of control is able to moderate the effect of organizational commitment on the performance of tax officers at South Makassar SMO. The results of this study give the meaning that the higher internal locus of control and organizational commitment owned by employees, the higher the performance of employees.

- There is a positive effect of pay-for-performance on the performance of tax officers at South Makassar SMO. The results of this study indicate that performance-based benefits can encourage and motivate employees to perform well.

- Locus of control is able to moderate the effect of pay-for-performance on the performance tax officers at South Makassar SMO. The results of this study indicate that the higher the internal locus of control and employee satisfaction on the performance-based benefits they received, the higher the performance of the employee.

Suggestions: Based on the conclusions as described above, it can be raised some suggestions related to increasing the performance of tax officers and advice for future research as follows. Increasing organizational commitment can be done by reviewing policies related to human resources management in order to foster a sense of identification, involvement and loyalty of employees to the organization, so that employees will feel accepted as an integral part of the organization, creating an atmosphere of mutual support between employees and organization, and also the willingness of employees to contribute with maximum effort for the organizational goals. Conduct monitoring and evaluation in relation to the conformity of performance-based benefits received by employees with employee performance indicators, employees' potentials, employees' activities, employees' contribution to organizational productivity, and employees' primary needs that must be filled. This is expected to satisfy personal goals and employee needs. Also, pay-for-performance should still be considered attractive by employees, so that employees feel appreciated for their work or efforts to achieve organizational goals.

Personal characteristic factor i.e. locus of control has relations within increasing the effect of organizational commitment and pay-for-performance on employees' performance. The internal locus of control has a stronger effect than the external. Therefore, employees should be given the opportunity to contribute, take 
the initiative in making decisions, so that employees are more confident and always try to improving his ability to complete the task as expected. The independent variables included in this study are still limited. Not all issues related to employees' performance are included in this study. Therefore, it is necessary to add other factors that influence the performance of employees so that future study will make more complete research. It's still needed to do study on locus of control aspect which acts as moderator variable to see consistency of the result in this study. In addition, there are other moderator variables that may increase the effect of organizational commitment and pay-for-performance that affecting on increasing employees' performance.

Limitations of Study: This study has some limitations that should be an attention for the future study. The limitations in this study are as follows. The questionnaire to assess the performance variable is susceptible to the possibility of perception bias because the respondent provides a performance assessment on his own (self-rating). The respondent is likely to give an excessive assessment of him or herself (covering up the actual situation).This study only using tax officers from South Makassar Small Taxpayer Office, there may be differences of perception of tax officers on other Tax Office.

\section{References}

Abdulloh. (2006). Pengaruh Budaya Organisasi, Locus of Control dan Kepuasan Kerja Terhadap Kinerja Karyawan pada Kantor Pelayanan Pajak Semarang Barat. Tesis. Semarang: Program Pasca Sarjana Magister Manajemen Universitas Diponegoro.

Allen, N. J. \& Meyer, J. P. (1990). The Measurement and Antecedents of Affective, Continuance and Normative Commitment to The Organization. Journal of Occupational Psychology, 63, 1-18.

Ayudiati, S. E. (2010). Analysis Pengaruh Locus of Control Terhadap Kinerja dengan Etika Kerja Islam sebagai Variabel Moderating (Studi pada Karyawan Tetap Bank Jateng Semarang). Skripsi. Semarang: Fakultas Ekonomi Universitas Diponegoro.

Bonner, S. E., Hastie, R., Sprinkle, G. B. \& Young, S. M. (2000). Review of The Effects of Financial Incentives on Performance in Laboratory Task: Implications for Management Accounting. Journal of Management Accounting Research (JMAR), 12, 19-64.

Chung, K. H. \& Megginson, L. C. (1981). Organization Behavior: Developing Managerial Skills. New York: Harper \& Row Publishers.

Coleman, D. F., Irving, G. P. \& Cooper, C. L. (1999). Another Look at The Locus of Control-Organizational Commitment Relationship: It Depends on The Form of Commitment. Journal of Organizational Behavior, 20, 995-1001.

Deci, E. L., Ryan, R. M. \& Koestner, R. (1999). A Meta-Analytic Review of Experiments Examining the Effects of Extrinsic Rewards on Intrinsic Motivation. Psychological Bulletin, 125(6), 627-668.

Dessler, G. (2012). Human Resource Management (13th Edition). New Jersey: Prentice Hall - Pearson Education, Inc.

Erdawati. (2015). Pengaruh Locus of Control dan Stres Kerja Terhadap Kinerja Pegawai di Dinas Kelautan dan Perikanan Kabupaten Pasaman Barat. E-Jurnal Apresiasi Ekonomi, 3(1), 39-45.

Gagne, M. \& Deci, E. L. (2005). Self-determination Theory and Work Motivation. Journal of Organizational Behavior, 26, 331-362.

Gibson, J. L., Ivancevich, J. M., Donnelly Jr., J. H. \& Konopaske, R. (2012). Organization: Behavior, Structure, Processes (14 Edition). New York: McGraw-Hill/Irwin.

Giri, E. E., Nimran, U., Hamid, D. \& Musadieq, M. A. (2016). The Effect of Organizational Culture and Organizational Commitment to Job Involvement, Knowledge Sharing, and Employee Performance: A Study on Regional Telecommunications Employees of PT Telkom East Nusa Tenggara Province, Indonesia. International Journal of Management and Administrative Sciences (IJMAS), 3(04), 20-33.

Ghozali, I. (2016). Aplikasi Analysis Multivariete dengan Program IBM SPSS 23. Semarang: Badan Peneribit Universitas Diponegoro.

Gomes, F. C. (2003). Manajemen Sumber Daya Manusia (Edisi II). Yogyakarta: Penerbit ANDI.

Hardani, L., Bachri, A. A. \& Dahniar. (2016). Pengaruh Tunjangan Kinerja dan Disiplin Kerja Terhadap Kinerja Pegawai Negeri Sipil Balai Karantina Pertanian Kelas I Banjarmasin. Jurnal Wawasan Manajemen, 4(1), 23-37.

Hellriegel, D. \& Slocum Jr., J. W. (2011). Organizational Behavior (13th Edition). Ohio: South-Western Cengage Learning. 
Hyatt, T. A. (1995). The Effects of Audit Firm Structure and Auditor's Locus of Control on Job Stress, Job Satisfaction, and Performance. Dissertation. Arizona: Faculty of the Committee on Business Administration The University of Arizona.

Hyatt, T. A. \& Prawitt, D. F. (2001). Does Congruence between Audit Structure and Auditors' Locus of Control Affect Job Performance. The Accounting Review, 76(2), 263-274.

Iqbal, S. M. J., Nabi, A. A., Muneer, S. \& Anuar, M. A. (2013). Impact of Training on Expectation of Employee and Employer: A comparative study. Information Management and Business Review, 5(12)

Julianingtyas, B. N. (2012). Pengaruh Locus of Control, Gaya Kepemimpinan dan Komitmen Organisasi Terhadap Kinerja Auditor. Universitas Negeri Semarang. Accounting Analysis Journal, 1(1), 7-14.

Konopaske, R., Ivancevich, J. M. \& Matteson, M. T. (2016). Organizational Behavior and Management (Eleventh Edition). New York: McGraw-Hill Education.

Luthans, F., Baack, D. \& Taylor, L. (1987). Organizational Commitment: Analysis of Antecedents. Human Relations, 40, 219-236.

Luthans, F. (2011). Organizational Behavior: An Evidence-Based Approach (12th Edition). New York: McGrawHill/Irwin.

Mangkunegara, A. A. \& Anwar, P. (2006). Evaluasi Kinerja SDM. Bandung:PT Refika Aditama.

Marganingsih, A. \& Dwi, M. (2010). Anteseden Komitmen Organisasi dan Motivasi:Konsekuensinya Terhadap Kinerja Auditor Intern Pemerintah. Jurnal Akuntansi dan Keuangan Indonesia, 7(1), 79-108.

Mathis, R. L. \& Jackson, J. H. (2011). Human Resource Management (13rd Edition). Ohio: South-Western Cengage Learning.

McMahon, B. (2007). Organizational Commitment, Relationship Commitment and Their Association with Attachment Style and Locus of Control. Thesis. Georgia: School of Psychology Georgia Institute of Technology.

McShane, S. L. \& Von Glinow, M. A. (2010). Organizational Behavior (5th Edition). New York: McGrawHill/Irwin.

Memari, N., Mahdieh, O. \& Marnani, A. B. (2013). The Impact of Organizational Commitment on Employees Job Performance. A Study of Meli Bank. Interdiciplinary Journal of Contemporary Research in Business, 5(5), 164-171.

Meyer, J. P. \& Allen, N. J. (1991). A Three Component Conceptualization of Organizational Commitment. Human Resource Management Review, 1, 61-89.

Meyer, J. P., Allen, N. J. \& Smith, C. A. (1993). Commitment to Organizations and Occupations: Extension and Test of A Three-Component Model. Journal of Applied Psychology, 78, 538-551.

Meyer, J. P., Stanley, D. J., Herscovitch, L. \& Topolnytsky, L. (2002). Affective, Continuance, and Normative Commitment to The Organization: A Meta-analysis of Antecedents, Correlates, and Consequences. Journal of Vocational Behavior, 61, 20-52.

Mguqulwa, N. (2008). The Relationship between Organizational Commitment and Work Performance in An Agricultural Company. Thesis. South Africa: Industrial and Organizational Psychology University of South Africa.

Mondy, R. W. \& Martocchio, J. J. (2016). Human Resource Management (14th Edition). England: Pearson Education Limited.

Mowday, R., Steers, R. M. \& Porter, L. (1979). The Measurement of Organizational Commitment. Journal of Vocational Behavior, 14(2), 224-247.

Murty, W. A. \& Hudiwinarsih, G. (2012). Pengaruh Kompensasi, Motivasi dan Komitmen Organisasional Terhadap Kinerja Karyawan Bagian Akuntansi (Studi Kasus Pada Perusahaan Manufaktur Di Surabaya). The Indonesian Accounting Review, 2(2), 215-228.

Muryanto, E. (2011). Pengaruh Kompensasi Terhadap Kinerja dengan Motivasi Kerja sebagai Variabel Moderating. Skripsi. Surakarta: Fakultas Ekonomi Universitas Sebelas Maret.

Noer, M. \& Raharjo, I. B. (2007). Pengaruh Budaya Organisasi, Locus of Control dan Kebijakan Sektor Publik Terhadap Kinerja Aparat Pelayanan Publik UPT Dipenda Bangkalan. Jurnal Akuntansi, Manajemen Bisnis dan Sektor Publik (JAMBSP), 3(2), 219-241.

Nydia, Y. T. (2012). Pengaruh Komitmen Organisasional Terhadap Kinerja Karyawan Lapangan SPBU COCO Pertamina MT Haryanto. Skripsi. Depok: Fakultas Ilmu Sosial dan Ilmu Politik Universitas Indonesia.

Presidential Regulation No. 37 Year 2015 regarding Performance-Based Benefit of the Directorate General of Taxes' Employee. 2015. Jakarta: the President of the Republic of Indonesia. 
Qamar, A., Muneer, S., Jusoh, A. \& Idris, H. (2013). The Relationship between Organizational Conduct and National Culture. Journal of Economics and Behavioral Studies, 5(2), 82-88

Pisca, Y. (2011). Pengaruh Insentif dan Locus of Control Terhadap Kinerja. Skripsi. Semarang: Fakultas Ekonomi Universitas Katolik Soegijapranata.

Robbins, S. P. \& Judge, T. A. (2013). Organizational Behavior (15th Edition). New Jersey: Pearson Education, Inc.

Rotter, J. B. (1966). Generalized Expectancies for Internal Versus External Control of Reinforcement. Psychological Monographs: General and Applied, 80(1), 1-28.

Rotter, J. B. (1990). Internal Versus External Control of Reinforcement. American Psychologist, 45, 489-493.

Saputra, K. A. K. (2012). Pengaruh Locus of Control Terhadap Kinerja dan Kepuasan Kerja Internal Auditor dengan Kultur Loka Tri Hita Karana sebagai Variabel Moderasi. Malang: Jurnal Akuntansi Multiparadigma, 3(1), 86-100.

Schermerhorn, J. R. Jr., Uhl-bien, M. \& Osborn, R. N. (2014). Organizational Behavior (13th Edition). New Jersey: John Wiley \& Sons, Inc.

Sidig, D. S. (2016). Efektivitas Kebijakan Besaran dan Kenaikan Tunjangan Kinerja Terhadap Peningkatan Kinerja Aparatur Sipil Negara: Studi pada Pusat Pembinaan Profesi Keuangan, Kementerian Keuangan Republik Indonesia. Skripsi tidak diterbitkan. Makassar: Departemen Akuntansi Fakultas Ekonomi dan Bisnis Universitas Hasanuddin.

Spector, P. E. (1982). Behavior in Organizations as a Function of Employee's Locus of Control. Psychological Bulletin, 91(3), 482-479.

Spector, P. E. (1988). Development of the Work Locus of Control Scale. Journal of Occupational Psychology, 61, 335-340.

Sujarweni, V. W. \& Endrayanto, P. (2012). Statistika untuk Penelitian. Yogyakarta: Graha Ilmu.

Stewart, G. L. \& Brown, K. G. (2011). Human Resource Management (2nd Edition). New Jersey: John Wiley \& Sons, Inc.

Weibel, A., Rost, K. \& Osterloh, M. (2009). Pay for Performance in The Public Sector-benefits and (Hidden) Costs. Journal of Public Administration Research and Theory, 2, 1-26. 